\title{
Evidence of silicic acid leakage to the tropical Atlantic via Antarctic Intermediate Water during Marine Isotope Stage 4
}

\author{
James D. Griffiths, ${ }^{1}$ Stephen Barker, ${ }^{1}$ Katharine R. Hendry, ${ }^{2,3}$ David J. R. Thornalley, ${ }^{1,4}$ \\ Tina van de Flierdt, ${ }^{5}$ Ian R. Hall, ${ }^{1}$ and Robert F. Anderson ${ }^{6}$ \\ Received 24 September 2012; revised 10 May 2013; accepted 16 May 2013; published 27 June 2013.
}

[1] Antarctic Intermediate Water (AAIW) and Subantarctic Mode Water (SAMW) are the main conduits for the supply of dissolved silicon (silicic acid) from the deep Southern Ocean (SO) to the low-latitude surface ocean and therefore have an important control on low-latitude diatom productivity. Enhanced supply of silicic acid by AAIW (and SAMW) during glacial periods may have enabled tropical diatoms to outcompete carbonate-producing phytoplankton, decreasing the relative export of inorganic to organic carbon to the deep ocean and lowering atmospheric $p \mathrm{CO}_{2}$. This mechanism is known as the "silicic acid leakage hypothesis" (SALH). Here we present records of neodymium and silicon isotopes from the western tropical Atlantic that provide the first direct evidence of increased silicic acid leakage from the Southern Ocean to the tropical Atlantic within AAIW during glacial Marine Isotope Stage $4(\sim 60-70 \mathrm{ka})$. This leakage was approximately coeval with enhanced diatom export in the NW Atlantic and across the eastern equatorial Atlantic and provides support for the SALH as a contributor to $\mathrm{CO}_{2}$ drawdown during full glacial development.

Citation: Griffiths, J. D., S. Barker, K. R. Hendry, D. J. R. Thornalley, T. van de Flierdt, I. R. Hall, and R. F. Anderson (2013), Evidence of silicic acid leakage to the tropical Atlantic via Antarctic Intermediate Water during Marine Isotope Stage 4, Paleoceanography, 28, 307-318, doi:10.1002/palo.20030.

\section{Introduction}

[2] Pockets of the ancient atmosphere trapped in Antarctic ice cores show that the atmospheric concentration of $\mathrm{CO}_{2}$ $\left(p \mathrm{CO}_{2}\right)$ was $80-100$ ppmv lower, during peak glacial times, than the preindustrial Holocene value of $\sim 280 \mathrm{ppmv}$ [Barnola et al., 1987; Petit et al., 1999]. It is generally agreed that the causal mechanism for the glacial-interglacial (G-IG) $p \mathrm{CO}_{2}$ change must be closely linked to the ocean carbon reservoir as this is the only active reservoir on Earth of sufficient size to account for the magnitude and frequency of the observed G-IG cycles in $p \mathrm{CO}_{2}$ [Broecker, 1982]. Many mechanisms have been proposed to explain all or part of the glacial decrease in $p \mathrm{CO}_{2}$, which range from changes in ocean

\footnotetext{
Additional supporting information may be found in the online version of this article.

${ }^{1}$ School of Earth and Ocean Sciences, Cardiff University, Cardiff, UK.

${ }^{2}$ Woods Hole Oceanographic Institution, Woods Hole, Massachusetts, USA.

${ }^{3}$ Now at School of Earth and Ocean Sciences, Cardiff University, Cardiff, UK.

${ }^{4}$ Now at Woods Hole Oceanographic Institution, Woods Hole, Massachusetts, USA.

${ }^{5}$ Department of Earth Science and Engineering, Imperial College London, London, UK.

${ }^{6}$ Lamont-Doherty Earth Observatory, Palisades, New York, USA.

Corresponding author: J. D. Griffiths, School of Earth and Ocean Sciences, Cardiff University, Cardiff CF10 3AT, UK. (griffithsjd@cf.ac. uk; jamesgriffit@gmail.com)

C2013. American Geophysical Union. All Rights Reserved. 0883-8305/13/10.1002/palo.20030
}

circulation [Sarmiento and Toggweiler, 1984] to biological processes [Sarmiento and Toggweiler, 1984; Martin, 1990] and the redistribution of carbonate sediment deposition [Berger, 1982]. It is generally thought though that the specific controls must be manifold [Sigman et al., 2010].

[3] Diatoms (unicellular algae) play a major role in the carbon, silicon, and nutrient budgets of the oceans [Nelson et al., 1995; Ragueneau et al., 2000] and may be important in regulating $p \mathrm{CO}_{2}$ through their influence on the global biological pump [Ragueneau et al., 2000]. For example, changes in the relative contributions of silica- versus carbonate-depositing organisms in the surface ocean can influence $p \mathrm{CO}_{2}$ by altering the ratio of organic to inorganic carbon exported to the deep sea [Archer and Maier-Reimer, 1994]. In the modern equatorial Atlantic, diatom biomass is limited by the availability of silicic acid $\left[\mathrm{Si}(\mathrm{OH})_{4}\right]$ [Nelson et al., 1995; Sarmiento et al., 2004], which is the major nutrient required by diatoms to build their protective outer frustules. Under conditions of plentiful silicic acid in surface waters, diatoms are often able to dominate primary productivity [Ragueneau et al., 2000]. Mesocosm experiments conducted with semicontinuous nutrient addition show that diatoms are able to outcompete the commonly occurring calcareous coccolithophore Emiliania huxleyi and other picoplankton when concentrations of $\mathrm{Si}(\mathrm{OH})_{4}$ are greater than $\sim 2 \mu \mathrm{M}$ and phosphate $\left(\mathrm{PO}_{4}^{3-}\right)$ and nitrate $\left(\mathrm{NO}_{3}^{-}\right)$are present in nonlimiting concentrations [Egge and Aksnes, 1992]. Other in situ studies suggest that the balance of silica and carbonate producers is strongly affected by local nutrient availability [Marañón et al., 1996; Leblanc et al., 2009]. Changes in 


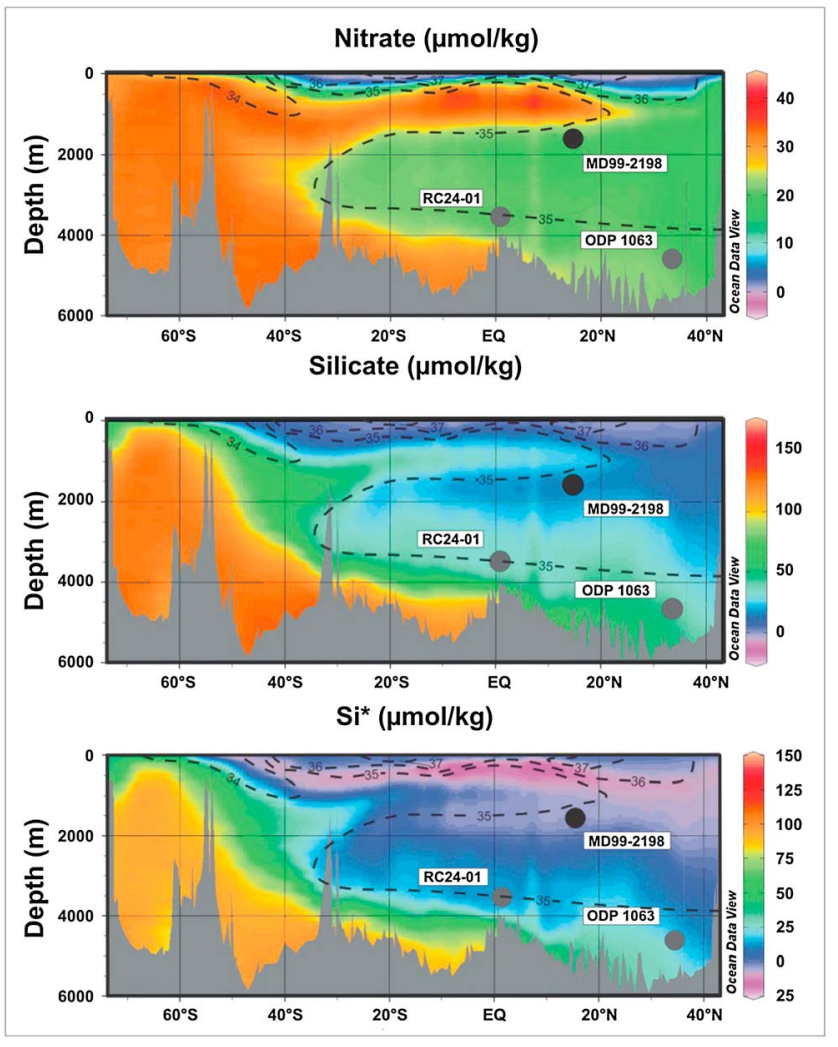

Figure 1. Concentrations of (top) nitrate, (middle) silicate, and (bottom) the pseudotracer $\mathrm{Si}^{*}$ from a transect through the western Atlantic from $\sim 75^{\circ} \mathrm{S}$ to $40^{\circ} \mathrm{N}$, with all core locations plotted by latitude and depth (note the hydrographic section is only relevant for MD99-2198, shown with a black marker; ODP 1063 and RC24-01 are shown by grey markers). AAIW is identifiable as a tongue of high-nitrate, low-Si* water extended from high southern latitude to low latitude $\left[\right.$ Schlitzer, 2000]. $\mathrm{Si}^{*}=\left[\mathrm{Si}(\mathrm{OH})_{4}\right]-\left[\mathrm{NO}_{3}^{-}\right] \quad[$ Sarmiento et al., 2004]. Salinity is indicated by the contours in black (values in PSS-78) [Schlitzer, 2000].

the supply ratio of $\mathrm{Si}(\mathrm{OH})_{4}$ to $\mathrm{NO}_{3}^{-}$to the surface of the equatorial Atlantic might then be expected to influence the ratio of silica to carbonate producers in this region [Brzezinski et al., 2002; Matsumoto et al., 2002].

[4] The supply of nutrients to the low-latitude Atlantic thermocline is determined by the flux and preformed chemistry of Antarctic Intermediate Water (AAIW) and Subantarctic Mode Water (SAMW) spreading north from their formation regions within the Southern Ocean (SO) [Sarmiento et al., 2004]. Analogous to SAMW, AAIW forms through the subduction near the Polar Front of waters originating from the Winter Water layer of the Bellingshausen Sea to the west of the Antarctic Peninsula [Sievers and Nowlin, 1984; Meredith et al., 1999]. Antarctic Surface Water (AASW) and SAMW have relatively low silicic acid contents with respect to other nutrients such as nitrate and phosphate, due to depletion of silicic acid by diatoms (Figure 1). It has been proposed that the densest varieties of SAMW transit the Drake Passage and contribute to AAIW in the Atlantic [McCartney, 1977; Hanawa and Talley, 2001]. The influence of AAIW at lower latitudes has been documented by its presence as a salinity minimum along an isopycnal $\left(\sigma_{0} \sim 27.3 \mathrm{~kg} \mathrm{~m}^{-3}\right)$ from $50^{\circ} \mathrm{S}$ to the Straits of Florida, via the north coast of South America and the Caribbean Sea, and from here extending northward to Cape Hatteras and as far northeast to $60^{\circ} \mathrm{N}, 20^{\circ} \mathrm{W}$, just south of Iceland [Tsuchiya, 1989].

[5] Southern Ocean (SO) surface waters are sourced from Upper Circumpolar Deep Water (UCDW), which upwells south of the Antarctic Polar Front (APF) and has a relatively high silicon:nitrate ratio ( $\mathrm{Si}: \mathrm{N} \approx 2$ to 3 ) [Schlitzer, 2000]. As a result, primary productivity in AASW is dominated by diatoms. Furthermore, diatoms in this region take up 4-5 times as much silicic acid per unit of organic matter than those from other regions of the world ocean [Pondaven et al., 2000; Brzezinski et al., 2001]. This is due partly to the fact that the Southern Ocean is iron limited, which increases the uptake of silicic acid relative to nitrate in diatoms [Takeda, 1998]. This process leaves AASW depleted in $\mathrm{Si}(\mathrm{OH})_{4}$ but high in preformed and (Figure 1) [Schlitzer, 2000]. If the silicic acid uptake of diatoms in surface waters of the Southern Ocean were to be decreased (for example, by an increase in the supply of $\mathrm{Fe}$ [e.g., Takeda, 1998]), then any unused silicic acid would "leak" to lower latitudes via AAIW (provided that it was not completely consumed by diatoms in the subantarctic zone) [Matsumoto et al., 2002]. Higher concentrations of silicic acid, conveyed to low latitudes by AAIW, could alleviate Si limitation there, allowing diatoms to increase their contribution to primary productivity, and potentially outcompete carbonate producers such as coccolithophorids [Brzezinski et al., 2002; Matsumoto et al., 2002]. The net result of such an ecological shift would be that $p \mathrm{CO}_{2}$ is drawn down through a combination of changes in surface and whole ocean alkalinity [Matsumoto et al., 2002; Matsumoto and Sarmiento, 2008]. This mechanism is known as the silicic acid leakage hypothesis (SALH).

[6] Here we test the SALH during the development of full glacial conditions at the Marine Isotope Stage (MIS) 5/4 boundary by producing records of authigenic (seawaterderived) neodymium $(\mathrm{Nd})$ isotopes, expressed as $\varepsilon_{\mathrm{Nd}}$ $\left[\varepsilon_{\mathrm{Nd}}=\left({ }^{143} \mathrm{Nd} /{ }^{144} \mathrm{Nd}_{\text {sample }} /{ }^{143} \mathrm{Nd} /{ }^{144} \mathrm{Nd}_{\text {CHUR }}-1\right) \times 10,000\right]$, with chondritic uniform reservoir $(\mathrm{CHUR})=0.512638$ [Jacobsen and Wasserburg, 1980], and sponge spicule silicon (Si) isotopes, expressed as $\delta^{30} \mathrm{Si}\left[\delta^{30} \mathrm{Si}=\left[\left[{ }^{30} \mathrm{Si} /{ }^{28} \mathrm{Si}\right)_{\text {sample }} /\right.\right.$ $\left.\left.\left.\left({ }^{30} \mathrm{Si} /{ }^{28} \mathrm{Si}\right)_{\text {standard }}\right]-1\right] \times 10^{3}\right]$, from a sediment core retrieved from the Tobago Basin (MD99-2198; $12.09^{\circ} \mathrm{N}, 61.23^{\circ} \mathrm{W}$; $1330 \mathrm{~m}$ water depth). The core site is currently influenced by AAIW (Figure 1) [Schlitzer, 2000]. The Nd isotope record provides an indication of the relative influences of intermediate waters sourced from northern versus southern high latitudes in the tropical Atlantic [Pahnke et al., 2008], while the silicon isotopes give information about changes in intermediate water $\left[\mathrm{Si}(\mathrm{OH})_{4}\right]$ at our core site [Hendry et al., 2010; Hendry and Robinson, 2012]. We also measured the sedimentary opal contents of MD99-2198 and the Bermuda Rise core ODP $1063\left(33^{\circ} 41^{\prime} \mathrm{N}, 57^{\circ} 37^{\prime} \mathrm{W} ; 4595 \mathrm{~m}\right.$ water depth) as well as (thorium-normalized) sedimentary opal accumulation rates in the eastern equatorial Atlantic (EEA) core $\mathrm{RC} 24-01\left(0^{\circ} 33^{\prime} \mathrm{N}, 13^{\circ} 39^{\prime} \mathrm{W} ; 3837 \mathrm{~m}\right.$ water depth) to gauge any effect on low-latitude diatom export productivity during the MIS 5/4 transition. In particular, we are interested in whether a SALH scenario could have 


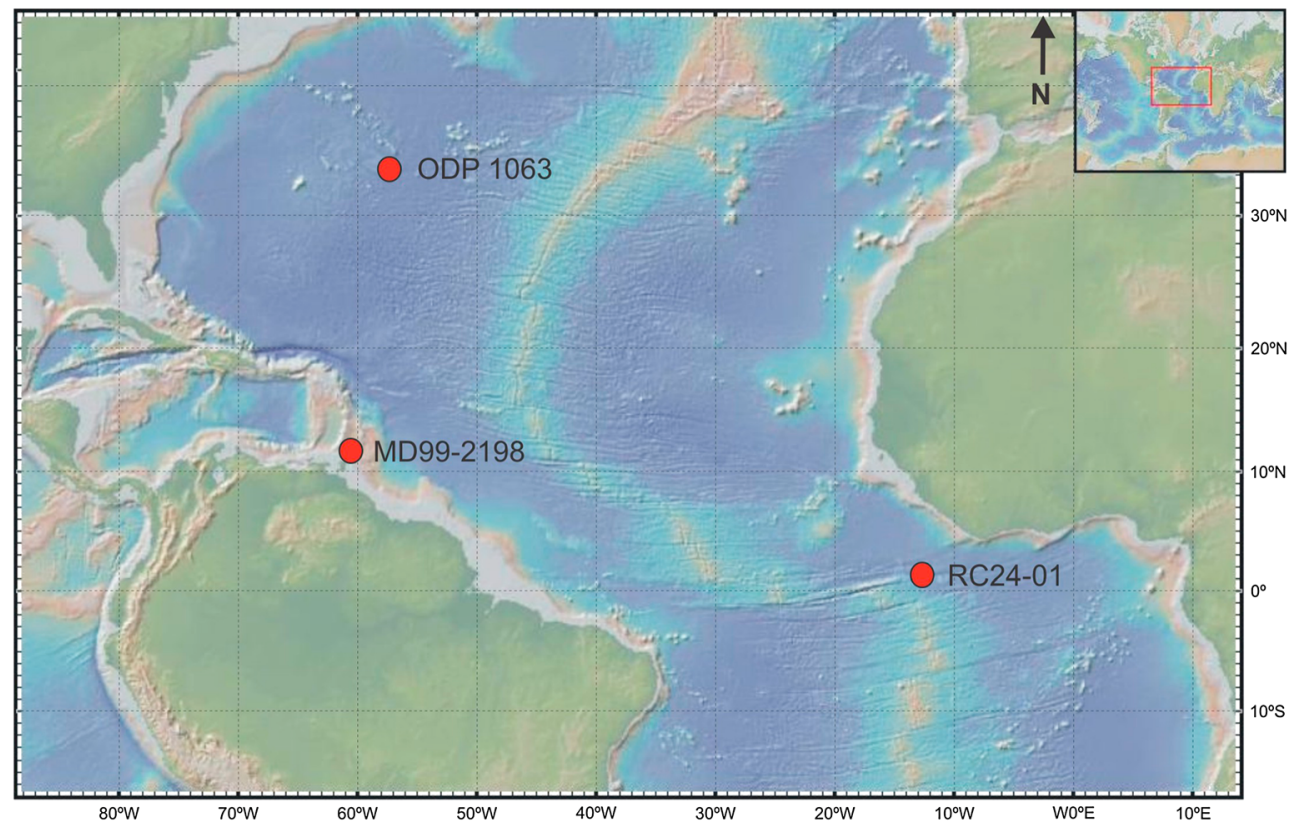

Figure 2. Core location map with marked positions of all cores used in this investigation.

played a role in the $\sim 46$ ppmv drawdown of $p \mathrm{CO}_{2}$ that occurred at the start of MIS 4 [Ahn and Brook, 2008]; a number of cores from the eastern equatorial Atlantic (EEA) indicate increased opal accumulation during MIS 4 [Gardner and Burckle, 1975; Stabell, 1986; Abrantes, 2001].

\section{Core Locations and Hydrography}

[7] MD99-2198 $\left(12.09^{\circ} \mathrm{N}, 61.23^{\circ} \mathrm{W} ; 1330 \mathrm{~m}\right.$ water depth) is situated in the Tobago Basin in the southeastern sector of the Caribbean Sea (Figure 2).

[8] We also generated opal accumulation records from the core RC24-01, situated in the EEA (Figure 2). The RC24-01 core site lies in the divergence created by the boundaries of the broad, westward flowing South Equatorial Current and the weaker, more variable eastward flowing North Equatorial Countercurrent [Bourles et al., 1999; Stramma and Schott, 1999]. For more details of core site hydrography, see the supporting information.

\section{Methods}

[9] Full details of the individual methods used in this study are given in the supporting information and are described only briefly below. Neodymium isotope ratios were measured on the dispersed Fe-Mn oxyhydroxide phase extracted from the fine $(<63 \mu \mathrm{m})$ fraction of the decarbonated bulk sediment from MD99-2198 sediment samples, following the same procedure as in Pahnke et al. [2008]. Silicon isotope ratios were measured on sponge spicules picked from the $63-215 \mu \mathrm{m}$ fraction of the previously separated coarse $(>63 \mu \mathrm{m})$ fraction of MD992198, according to the protocol of Hendry et al. [2010]. Concentrations of protactinium $\left({ }^{231} \mathrm{~Pa}\right)$, thorium $\left({ }^{230} \mathrm{Th}\right.$ and $\left.{ }^{232} \mathrm{Th}\right)$, and uranium $\left({ }^{234} \mathrm{U}\right.$ and $\left.{ }^{238} \mathrm{U}\right)$ in $\mathrm{RC} 24-01$ were measured on $\sim 0.1 \mathrm{~g}$ of bulk sediment, according to the method of Anderson and Fleer [1982] and Fleisher and
Anderson [2003]. Sedimentary opal measurements were made on bulk sediment samples from MD99-2198, RC24-01, and ODP 1063 using the wet alkaline extraction method of Mortlock and Froelich [1989].

\section{Core Age Control}

[10] We used the North Greenland Ice Core Project (NGRIP) $\delta^{18} \mathrm{O}$ record (using the Greenland Ice Core Chronology 2005 timescale) [Andersen et al., 2007] for 0-60 ka and a speleothem-tuned age model prior to $60 \mathrm{ka}$ [Barker et al., 2011] as a tuning target for all age models used in this study. Age control for MD99-2198 was initially based on a low-resolution record of benthic $\delta^{18} \mathrm{O}$ (R. Zahn, unpublished data, 2010; and see the supporting information) that allowed identification of MIS 4 and fine tuned by aligning a higher-resolution planktonic $\delta^{18} \mathrm{O}$ record (Globigerinoides ruber, white, picked from the $250-315 \mu \mathrm{m}$ fraction) with the NGRIP $\delta^{18} \mathrm{O}$ record (Figure 3 ). This approach assumes inphase behavior between millennial-scale oscillations in the tropics and the Northern Hemisphere temperature. We suggest that this is reasonable, because these regions are linked through meridional heat transport and the position of the Intertropical Convergence Zone (ITCZ) (which is sensitive to changes in North Atlantic temperature) [Hüls and Zahn, 2000; Peterson et al., 2000; Lea et al., 2003; Cruz et al., $2005]$. It has also been demonstrated that the primary control on the $\delta^{18} \mathrm{O}$ of rainfall over tropical South America is the amount of precipitation, which is modulated by the position of the ITCZ [Vuille et al., 2003; Cruz et al., 2005]. The uncertainty associated with individual control points in our age model (with respect to the Greenland record to which it is tuned) depends on our ability to identify the correct transitions for tuning and the precision with which tuning can be performed (which is dependent on the duration of the transition). However, much of our discussion will be based on the MIS 4 interval, during which we have no robust age control 


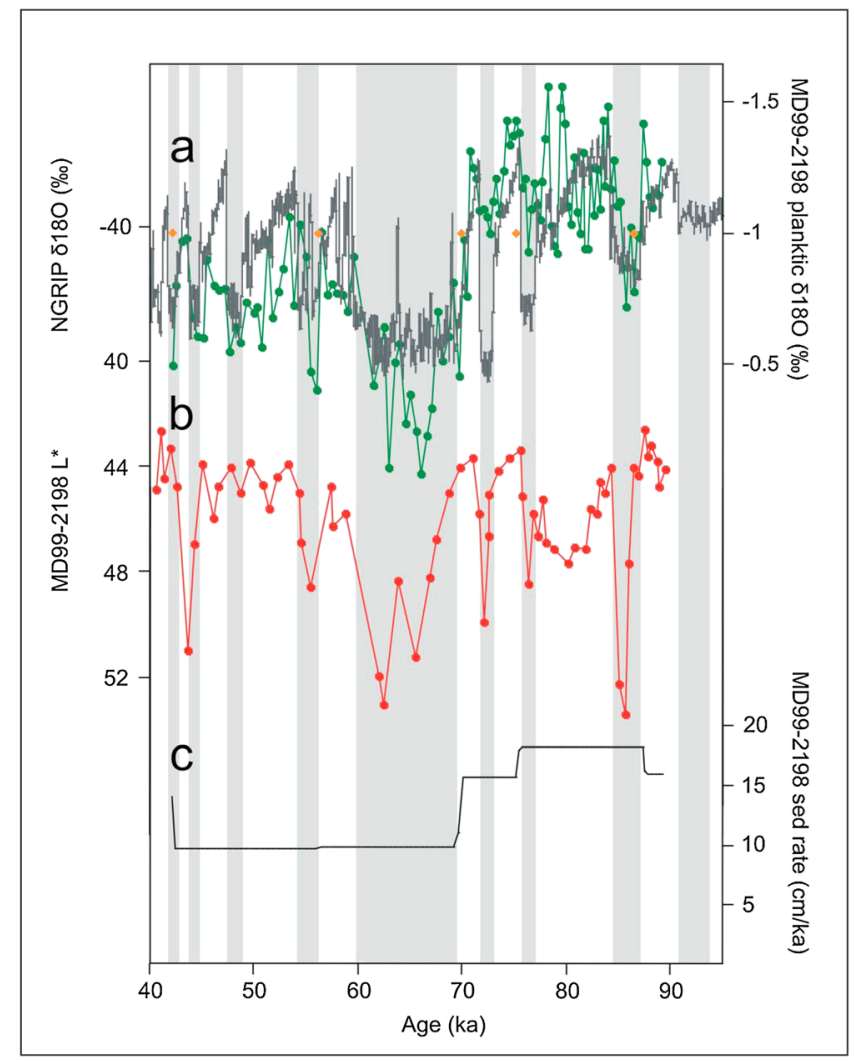

Figure 3. (a) NGRIP $\delta^{18} \mathrm{O}$ (grey curve) [Andersen et al., 2007], adjusted to the Hulu-Sanbao speleothem record [Wang et al., 2001, 2008], with MD99-2198 planktic foraminiferal $\delta^{18} \mathrm{O}$ record of Globigerinoides ruber (white), tuned to the NGRIP record (overlain green curve with tie points shown in orange); (b) MD99-2198 $\mathrm{L}^{*}$ core reflectance [Hüls and Zahn, 2000] (red curve); (c) MD99-2198 core sedimentation rate $(\mathrm{cm} / \mathrm{ka}$ ) (black curve). Northern Hemisphere cold periods are marked by grey bands.

within MD99-2198. We therefore present our discussion in terms of early, mid, or late MIS 4, etc. Fortunately, records obtained from individual cores can be compared together unambiguously, and several of our records have been obtained in such a way.

[11] The $\mathrm{L}^{*}$ reflectance index (a measure of sediment brightness) may be used to distinguish sedimentological components such as free and bound $\mathrm{Fe}, \mathrm{CaCO}_{3}, \mathrm{Fe}$ minerals (e.g., goethite), and clay [Rogerson et al., 2006]. A highresolution record of core reflectance (similar to $\mathrm{L}^{*}$ ) from the western tropical Atlantic was used to identify a link between sediment reflectance changes in the Cariaco Basin (northern coastal Venezuela) and Greenland ice core $\delta^{18} \mathrm{O}$ changes, thereby demonstrating a clear linkage of the tropical hydrological cycle with high northern latitude climate [Peterson et al., 2000]. We note that the record of L* from MD99-2198 [Hüls and Zahn, 2000] reveals a similar relationship with Greenland temperature when placed on our timescale (Figure 3).

[12] Age control for ODP 1063 is explained in detail in a study by Thornalley et al. [2013] and briefly was obtained by tuning core reflectance and magnetic susceptibility to records of orbital precession and obliquity [Grützner et al.,
2002], with further refinement by tuning the planktic $\delta^{18} \mathrm{O}$ record to NGRIP $\delta^{18} \mathrm{O}$ (Figure 4). Age control for RC24-01 was initially based on a low-resolution $\delta^{18} \mathrm{O}$ record (derived from the thermocline-dwelling Neogloboquadrina dutertrei) from the same core [Verardo and McIntyre, 1994], which was tuned to Mapping Spectral Variability in Global Climate Project (SPECMAP) [Martinson et al., 1987]. The age model was then fine tuned using a new high-resolution $\delta^{18} \mathrm{O}$ record from $G$. ruber, and the consistency of the age

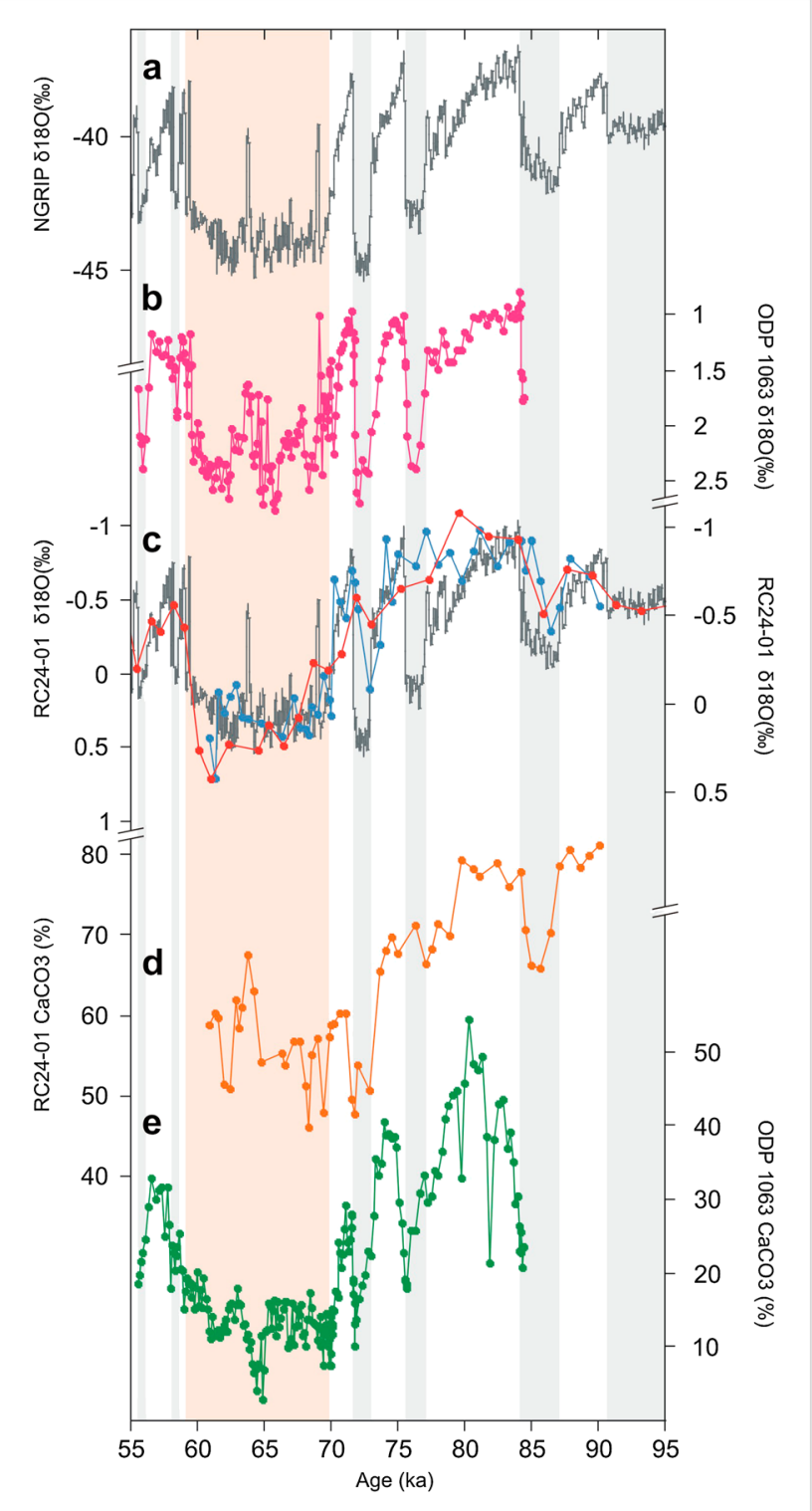

Figure 4. (a) NGRIP $\delta^{18} \mathrm{O}$ (grey curve) [Andersen et al., 2007], adjusted to the Hulu-Sanbao speleothem record [Wang et al., 2001, 2008]; (b) ODP 1063 planktic $\delta^{18} \mathrm{O}$ (pink curve) [Thornalley et al., 2013]; (c) RC24-01 planktic $\delta^{18} \mathrm{O}$ (G. ruber, this study) (blue curve), with RC24-01 planktic $\delta^{18} \mathrm{O}$ (N. dutertrei, Verardo and McIntyre [1994]) (red curve), plotted over the NGRIP $\delta^{18} \mathrm{O}$ record; (d) RC24-01 $\% \mathrm{CaCO}_{3}$ (this study; orange curve); (e) ODP $1063 \%$ $\mathrm{CaCO}_{3}$ (green curve) [Thornalley et al., 2013]. Northern Hemisphere cold periods are marked by grey bands, and MIS 4 is marked by a light orange band. 
model was checked by comparing the $\% \mathrm{CaCO}_{3}$ record of RC24-01 to that of ODP 1063 (Figure 4) [Thornalley et al., 2013].

\section{Results and Discussion}

\subsection{Neodymium (Nd) Isotopic Changes MIS 5a-4}

[13] Pore water profiles of rare earth elements from marine pelagic sediments demonstrate that under oxic to suboxic conditions, trace metals such as $\mathrm{Nd}$ are scavenged from seawater and incorporated into Fe-Mn oxyhydroxide coatings in the uppermost few centimeters of sediment [Haley et al., 2004]. This observation has been exploited in a number of studies to reconstruct seawater $\mathrm{Nd}$ isotopic compositions using such dispersed $\mathrm{Fe}-\mathrm{Mn}$ hydroxide coatings, for example [Rutberg et al., 2000; Bayon et al., 2002; Piotrowski et al., 2005; Gutjahr et al., 2007, 2008; Pahnke et al., 2008]. Extracting the authigenic Nd signal from oxyhydroxide coatings by sequential leaching, Pahnke et al. [2008] found that the core top value of MD99-2198 agreed within one epsilon unit with the seawater $\mathrm{Nd}$ isotopic compositions from stations near the Tobago Basin [Piepgras and Wasserburg, 1987], even though strontium ( $\mathrm{Sr}$ ) isotopes measured on the same leachates deviated significantly from seawater. This observation confirms the mass balance calculations by Gutjahr et al. [2007], implying that even in cases of significant detrital contamination of the $\mathrm{Sr}$ isotope signal, $\mathrm{Nd}$ isotopes can still preserve an authigenic signature. We used exactly the same leaching protocol as in Pahnke et al. [2008], providing confidence that Fe-Mn leachate results of bulk sediments at this site yield robust authigenic $\mathrm{Nd}$ isotopic compositions.

[14] Seawater Nd isotopes across the MIS 5/4 transition from MD99-2198 show a range in $\varepsilon_{\mathrm{Nd}}$ from -9.1 to -11.0 (Figure 5, red curve c). Relatively unradiogenic values $\left(\varepsilon_{\mathrm{Nd}}=-10\right.$ to -11$)$ are displayed during the latter part of MIS 5, which suggest a significant influence of Northern Component Water (NCW) on the western tropical Atlantic during MIS 5a. These values are furthermore similar to the core top value of -11 [Pahnke et al., 2008], which reflects modern mixing of North Atlantic Deep Water (NADW) with a typical $\varepsilon_{\mathrm{Nd}}=-13$ to -14 [Piepgras and Wasserburg, 1987; Lacan and Jeandel, 2005] with a smaller proportion of more radiogenic AAIW $\left(\varepsilon_{\mathrm{Nd}}=-7\right.$ to -9$)$ [Piepgras and Wasserburg, 1982; Jeandel, 1993; Stichel et al., 2012].

[15] During early MIS 4, our record shows an abrupt change to a less negative (more radiogenic) $\varepsilon_{\mathrm{Nd}}$, beginning around the end of D-O 19 and reaching a maximum during mid MIS 4. Subsequently, the $\varepsilon_{\mathrm{Nd}}$ values decrease into the latter half of MIS 4, suggesting a slight enhancement of NCW influence. The most radiogenic value attained at $\sim 65 \mathrm{ka}$ is $\varepsilon_{\mathrm{Nd}}=-9.1$, which is approaching the South Atlantic/AAIW end-member. The $\mathrm{Nd}$ isotopic record also demonstrates a more negative excursion (more AAIW) during MIS $3(\sim 55 \mathrm{ka})$. Unfortunately, Nd data could not be attained for warm D-O 19 and cold D-O 20 (see the supporting information).

\section{Silicon (Si) Isotopic Changes MIS 5a-4}

[16] The $\delta^{30} \mathrm{Si}$ data (Figure 5, blue curve d) obtained in this study are interpreted to reflect changes in the ambient silicic

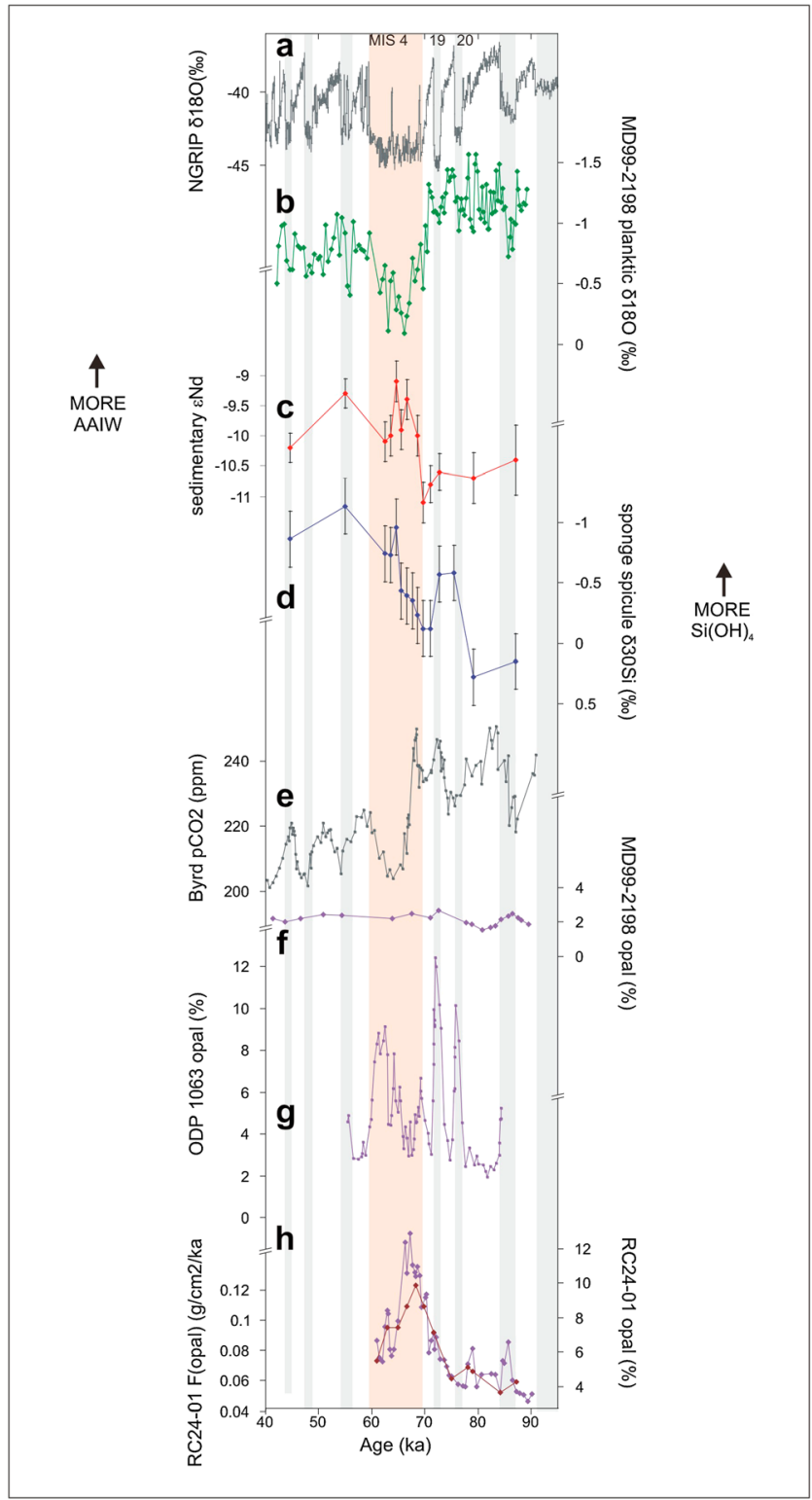

Figure 5. (a) NGRIP $\delta^{18} \mathrm{O}$ [Andersen et al., 2007], adjusted to the Hulu-Sanbao speleothem record [Wang et al., 2001, 2008]. (b) MD99-2198 planktic $\delta^{18} \mathrm{O}$ (\%) (green curve). (c) MD99-2198 sedimentary $\varepsilon_{\mathrm{Nd}}$ (red curve); error bars are 2 sigma standard deviation at the $95 \%$ confidence limit (2бSD). (d) MD99-2198 sponge spicule $\delta^{30} \mathrm{Si}$ (blue curve); error bars are $2 \sigma \mathrm{SD}$. (e) Byrd (Antarctica) ice core $p \mathrm{CO}_{2}$ [Ahn and Brook, 2008]. (f) MD99-2198 opal (\%) (purple curve). (g) ODP 1063 opal (\%) (purple curve). (h) RC24-01 opal (\%) (purple curve), overlain with RC24-01 thoriumnormalized preserved opal flux rate $\left(\mathrm{g} / \mathrm{cm}^{2} / \mathrm{ka}\right.$ ) (brown curve). All percent opal measurements are plotted on the same $y$ axis. Northern Hemisphere cold periods are marked by grey bands, and MIS 4 (light orange shading) and cold D-O 19 and 20 are annotated.

acid concentration of AAIW using the relationship in equation (1) [Hendry and Robinson, 2012], using the observed range in AAIW silicon isotope composition $\left(\delta^{30} \mathrm{Si}(\mathrm{OH})_{4}\right)$. Seawater $\delta^{30} \mathrm{Si}(\mathrm{OH})_{4}$ values for AAIW in the modern ocean 
range from approximately $+1.5 \%$ [Cardinal et al., 2005; Hendry et al., 2010] to $+2 \%$, measured in the winter mixed layer where intermediate waters form by subduction [de Souza et al., 2012].

$$
\left[S i(\mathrm{OH})_{4}\right]=\left(270 /\left(\Delta \delta^{30} S i+6.54\right)\right)-53 \quad\left(R^{2}=0.83\right)
$$

where $\Delta \delta^{30} \mathrm{Si}=\delta^{30} \mathrm{Si}_{\text {sponge }}-\delta^{30} \mathrm{Si}_{\text {seawater }}$.

[17] There exists the possibility that the $\delta^{30} \mathrm{Si}(\mathrm{OH})_{4}$ of AAIW may not have been the same as that in the modern ocean due to differences in biological utilization of silicic acid in the Southern Ocean or to whole ocean changes in the silicon budget. However, we suggest that AAIW is unlikely to have changed significantly and probably remained in the range of +1.5 to $+2 \%$. During periods of lower $\left[\mathrm{Si}(\mathrm{OH})_{4}\right](70-90 \mathrm{ka})$, biological utilization is likely to have been relatively high, resulting in relatively heavy AAIW $\delta^{30} \mathrm{Si}(\mathrm{OH})_{4}(\sim 2 \%)$ [de Souza et al., 2012]. During periods of leakage, biological utilization is likely to have been relatively lower, such that the AAIW $\delta^{30} \mathrm{Si}(\mathrm{OH})_{4}$ is likely to have been lighter. Although there are no published records from $>60 \mathrm{ka}$, the greatest glacial-interglacial change in subantarctic diatom opal $\delta^{30} \mathrm{Si}$ is $\sim 0.4 \%$ o [Beucher et al., 2007]. Assuming a constant diatom $\mathrm{Si}$ isotope fractionation factor [de la Rocha et al., 1997], these records suggest that the $\delta^{30} \mathrm{Si}(\mathrm{OH})_{4}$ of AAIW was $0.4 \%$ lighter during periods of silicic acid leakage (40-60 ka). Hence, our reconstruction (shown in Figure 6), assuming $\delta^{30} \mathrm{Si}(\mathrm{OH})_{4}$ of AAIW of $+1.5-2 \%$, encapsulates the possible shifts in $\left[\mathrm{Si}(\mathrm{OH})_{4}\right]$ of AAIW between 40 and $90 \mathrm{ka}$ (ranging from $<5 \mu \mathrm{M}$ at $80-90 \mathrm{ka}$ to $10-25 \mu \mathrm{M}$ at $40-50 \mathrm{ka})$. In addition, modern Southern Ocean sponges that show spicule $\delta^{30} \mathrm{Si}$ values similar to our records between 80 and 90 ka grow in subantarctic waters with $\left[\mathrm{Si}(\mathrm{OH})_{4}\right] \sim 2 \mu \mathrm{M}$, while those that yield spicule $\delta^{30} \mathrm{Si}$ similar to our records between 40 and 50 ka grow in waters with $\left[\mathrm{Si}(\mathrm{OH})_{4}\right] \sim 10-15 \mu \mathrm{M}$ [Hendry et al., 2010; Wille et al., 2010].

[18] We infer a change in the silicic acid content of AAIW over a timescale $<10 \mathrm{ka}$, which is of the same order as the oceanic residence time of dissolved silicon, estimated at $\sim 10-15 \mathrm{ka}$ [Tréguer et al., 1995; Georg et al., 2009]. We therefore suggest that even large changes in silicon input to the oceanic reservoir could not alter its silicon isotope composition significantly over the timescale of our record. Our results suggest an increase in ambient $\left[\mathrm{Si}(\mathrm{OH})_{4}\right]$ of $\sim 15$ to $20 \mu \mathrm{M}$ throughout early MIS 4 (Figure 6). This increase would probably have been sufficient to alleviate Si limitation on low-latitude diatom production [Egge and Aksnes, 1992].

[19] Silicic acid leakage during MIS 4 appears to have had no effect on the diatom export productivity at the MD992198 core site (Figure 5, purple curve f). However, the record of percent opal from ODP 1063 (Figure 5, purple curve g) demonstrates a sustained increase within MIS 4 and also during D-O 19 and 20. The records of percent opal (Figure 5, purple curve h) and thorium-normalized opal flux (Figure 5, brown curve h) from RC24-01 also reveal higher values during MIS 4. We do note significant differences in detail between the opal records from ODP 1063 and RC24-01. In part, these may reflect differences in resolution (e.g., across D-O 19 and 20), but, and as discussed below, they may also reflect differences in the transferral of silicic acid from intermediate depths to the photic zone.

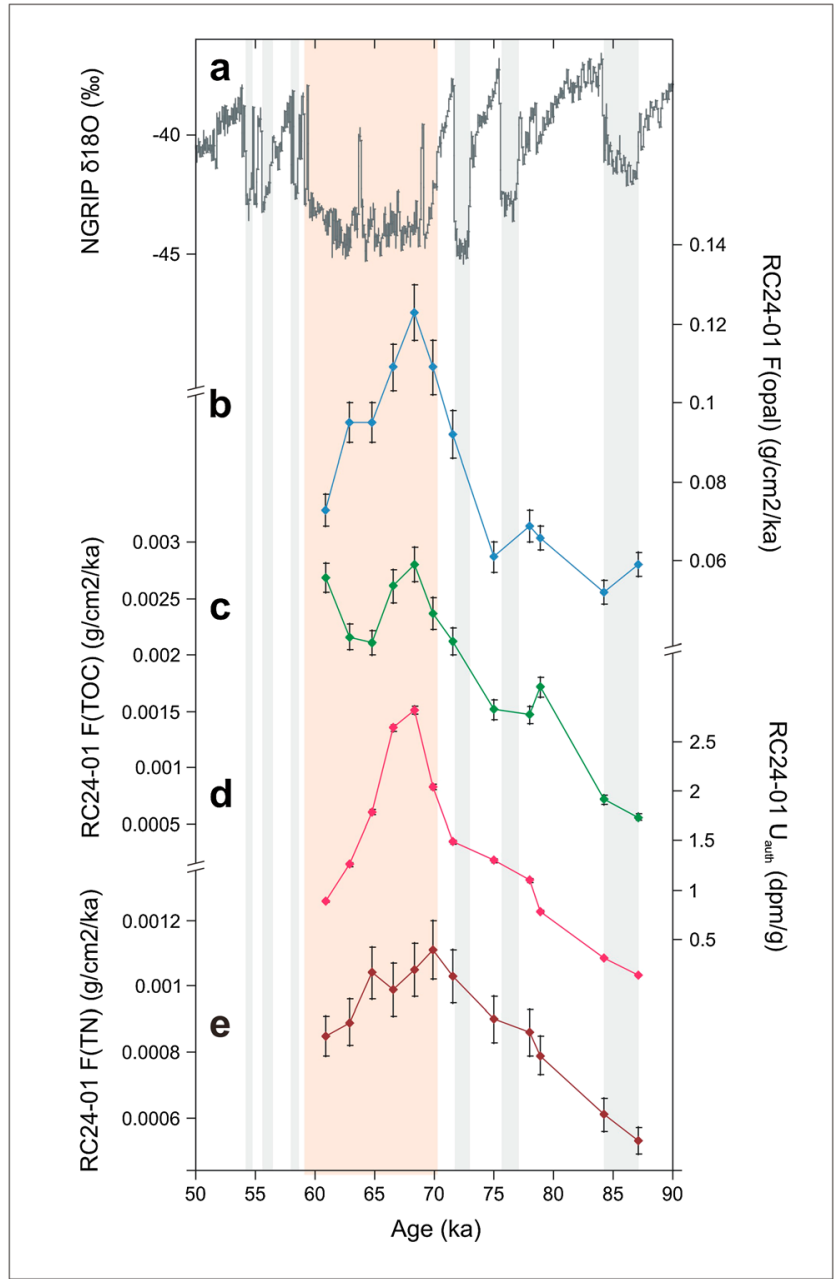

Figure 6. (a) NGRIP $\delta^{18} \mathrm{O}(\%)$ (grey curve) [Andersen et al., 2007], adjusted to the Hulu-Sanbao speleothem record [Wang et al., 2001, 2008]. (b) RC24-01 opal flux rate $\left(\mathrm{g} / \mathrm{cm}^{2} / \mathrm{ka}\right.$ ) (blue curve); error bars are $2 \sigma \mathrm{SD}$. (c) RC24-01 total organic carbon flux rate $\left(\mathrm{g} / \mathrm{cm}^{2} / \mathrm{ka}\right.$ ) (green curve); error bars are $2 \sigma \mathrm{SD}$. (d) RC24-01 authigenic uranium (dpm/g) (pink curve), used as a proxy for organic carbon flux; error bars are $2 \sigma \mathrm{SD}$. (e) RC24-01 total nitrogen flux rate $\left(\mathrm{g} / \mathrm{cm}^{2} / \mathrm{ka}\right)$ (brown curve); error bars are $2 \sigma \mathrm{SD}$. All proxies record an opal-driven increase in primary productivity in the EEA during MIS 4. Northern Hemisphere cold periods are marked by grey bands, and MIS 4 (light orange shading) and cold D-O 19 and 20 are annotated.

\section{Controls on the Nd Isotopic Record}

[20] The records of $\varepsilon_{\mathrm{Nd}}$ and $\delta^{30} \mathrm{Si}$ from MD99-2198 (Figure 5) suggest a major reorganization in the low-latitude oceans at the MIS 5/4 transition. The $\varepsilon_{\mathrm{Nd}}$ during MIS $5 \mathrm{a}$ is -10 to -11 , similar to modern values, and is analogous to the modern scenario of Atlantic Intermediate Water (AIW), a combination of AAIW and Upper North Atlantic Deep Water [Wüst, 1964; Haddad and Droxler, 1996], bathing the MD99-2198 core site. The reconstruction of $\varepsilon_{\mathrm{Nd}}$ in MIS 5a further implies that some variety of Northern Component Water (NCW), with a similar Nd isotopic signature to modern NADW, was influencing the mid-depth 
western tropical Atlantic in this interval. This inference is in agreement with studies from several locations in the Atlantic that employ sedimentary ${ }_{\mathrm{xs}}\left({ }^{231} \mathrm{~Pa} /{ }^{230} \mathrm{Th}\right)_{0}$ as an indicator of the strength of Atlantic Meridional Overturning Circulation changes as well as $\varepsilon_{\mathrm{Nd}}$ [Rutberg et al., 2000; Piotrowski et al., 2005; Guihou et al., 2010].

[21] In order to understand the $\varepsilon_{\mathrm{Nd}}$ record generated from MD99-2198, we considered the potential effect that other water masses could have had on the $\mathrm{Nd}$ isotopic record at our core site. Southern and western Indian Ocean intermediate and deep waters have $\varepsilon_{\mathrm{Nd}} \approx-7$ to -9 (reflecting dominance of northward flowing circumpolar water) [Piepgras and Wasserburg, 1982; Bertram and Elderfield, 1993; Jeandel, 1993; Jeandel et al., 1998; Stichel et al., 2012], which are similar to the $\mathrm{Nd}$ isotopic composition of AAIW. Deep and intermediate waters from the Indian Ocean therefore have the potential to have influenced the intermediatedepth Tobago Basin and contributed to the more radiogenic values of $\varepsilon_{\mathrm{Nd}}$ recorded during MIS 4 . A mechanism for the exchange of heat and salt in surface and intermediate waters between the Indian Ocean and the South Atlantic is the intermittent shedding of large-scale rings, filaments, and eddies of Indian Ocean water from the Agulhas current and retroflection off South Africa [de Ruijter et al., 1999]. However, we suggest that Agulhas leakage is unlikely to have influenced the $\mathrm{Nd}$ isotopic record of MD99-2198, as a study of the exchange of heat and salt between the Atlantic and Indian Oceans via the Agulhas retroflection suggests that the input of Indian Ocean water into the South Atlantic was relatively minor during MIS 4 [Peeters et al., 2004].

[22] Another water mass that may have influenced the hydrography and hence the $\mathrm{Nd}$ isotopic composition in the Tobago Basin during MIS 5/4 is Mediterranean Overflow Water (MOW). Modern MOW at the outflow from the Strait of Gibraltar is characterized by a $\varepsilon_{\mathrm{Nd}}$ of $\approx-9.5$ [Tachikawa et al., 2004], a value within the error of the maximum $\varepsilon_{\mathrm{Nd}}$ recorded during MIS 4 in MD99-2198. The net flux of MOW into the North Atlantic was lower in MIS 2 than during Northern Hemisphere stadials and Heinrich events [Voelker et al., 2006] and therefore was probably low during MIS 4 but cannot be fully excluded as a potential contributor to the $\mathrm{Nd}$ isotopic excursion recorded during MIS 4 in MD99-2198.

[23] Besides considering the effect that changes in volume (and hence mixing proportions) of water masses in the Tobago Basin may have on seawater $\mathrm{Nd}$ isotopes, it is also possible for vertical changes in water mass boundaries to have had an influence [Xie et al., 2012]. MD99-2198 lies at the lower limit of modern AAIW (1330 m; see Figure 1) and may therefore be sensitive to changes in the depth of the boundary between AAIW and Glacial North Atlantic Intermediate Water (GNAIW), a glacial analogue of NADW [Oppo and Lehman, 1993]. If AAIW shoaled to $\sim 1000 \mathrm{~m}$ during glacial periods, as predicted to have occurred in the Last Glacial Maximum [Curry and Oppo, 2005], or was absent, the MD99-2198 core site would have been bathed by GNAIW [Curry and Oppo, 2005; Marchitto and Broecker, 2006]. However, GNAIW probably had a similar $\mathrm{Nd}$ isotopic signature to modern NADW [van de Flierd t et al., 2006; Foster et al., 2007] and therefore would result in a shift to lower $\varepsilon_{\mathrm{Nd}}$ values during MIS 4, which is contrary to the higher values observed in MD99-2198 during
MIS 4. Hence, we discount shoaling of the AAIW-GNAIW boundary as an influence on our $\mathrm{Nd}$ isotopic record.

[24] One last point for consideration is our implicit assumption of stability in the $\mathrm{Nd}$ isotopic compositions of the source region of southern water masses. This assumption may, however, be compromised by the fact that decreased export of NADW/GNAIW to the Southern Ocean will have an effect on the $\mathrm{Nd}$ isotopic composition of water masses formed in the Southern Ocean. Data extracted from a deepsea coral skeleton from the Drake Passage indicate that intermediate waters during Heinrich Stadial (HS) 1 ( $16.7 \mathrm{ka})$ became more radiogenic [Robinson and van de Flierdt, 2009], probably due to reduced input of North Atlantic-sourced Nd to the Drake Passage, associated with decreased NADW export [Keigwin et al., 1994; McManus et al., 2004], resulting in more "Pacific-like" values in the Southern Ocean. It remains to be seen whether a similar scenario could have made the $\mathrm{Nd}$ isotopic composition of SAMW and AAIW source regions more radiogenic during MIS 4. Heinrich Stadials have been considered as times with particularly perturbed deep ocean circulation [Keigwin et al., 1994; McManus et al., 2004], and hence, it might be that changes in seawater $\mathrm{Nd}$ isotopes in the Southern Ocean of similar magnitude during early MIS 4 are less likely. Therefore, while our preferred interpretation is that elevated values of $\varepsilon_{\mathrm{Nd}}$ during MIS 4 reflect increased influence of AAIW in the Tobago Basin, we cannot exclude the possibility that the excursion was a result of decreased NADW export.

\section{Controls on the Si Isotopic Record}

[25] The results of this study take on more significance when they are examined alongside the $\mathrm{Si}$ isotope data. The correlation $(\mathrm{r}=-0.7$ at $\mathrm{p}<0.05)$ between the $\mathrm{Nd}$ isotopic record and the silicon isotopic record of silicic acid concentrations in MD99-2198 (Figure 5) implies that the water's origin was in the subantarctic zone $(\sim 100 \mu \mathrm{M}$ of silicic acid) [Schlitzer, 2000] because the middle and northern Atlantic is depleted in silicic acid due to depletion by diatoms in subtropical anticyclonic gyre systems [Levitus et al., 1993]. The only region of the ocean that contains sufficient silicic acid to affect a significant change in the silicic acid content of AAIW is the deep SO [Schlitzer, 2000]. However, there are also important differences between the $\mathrm{Nd}$ and $\mathrm{Si}$ isotopic records. The most notable feature is that the increase in $\varepsilon_{\mathrm{Nd}}$ occurs rapidly at the start of MIS 4 , whereas the $\delta^{30} \mathrm{Si}$ value decreases more gradually throughout early MIS 4. Second, the most negative $\delta^{30} \mathrm{Si}$ value (the greatest silicic acid concentration) occurs during MIS 3 . If this was not reflected by an increase in low-latitude diatom productivity, it might reflect variations in the upwelling of intermediate waters into the photic zone (see below).

[26] The most important sources of dissolved silicon to the ocean are rivers [Tréguer et al., 1995], which must also be considered as potential suppliers of silicic acid to the Tobago Basin during MIS 4. The modern eastern Caribbean Sea is influenced by freshwater input from both the Orinoco River [Chérubin and Richardson, 2007] and the Amazon River [Chérubin and Richardson, 2007; Molleri et al., 2010]. However, input of sediment to the eastern Caribbean Sea during glacial periods is likely to have been lower from the Amazon River, due to decreased rainfall 
over South America because of a southward shift in the position of the ITCZ [Peterson and Haug, 2006]. On the other hand, sedimentary input from the Orinoco River may have been higher [Bowles and Fleischer, 1985] because despite the fact that Orinoco outflow is also modulated by the position of the ITCZ, the proximity of the Aves Ridge to the Orinoco plume may cause volumetric increases in Orinoco River water during glacial lowstand [Bowles and Fleischer, 1985]. Alternatively, other evidence suggests that Orinoco River water is not a significant contributor of dissolved silicon to the Tobago Basin; first, Orinoco River water generally contains low concentrations of dissolved and suspended constituents due to a high runoff [Lewis and Saunders, 1989]. More importantly, sediments from the lower Orinoco River display a less radiogenic $\mathrm{Nd}$ isotopic composition $\left(\varepsilon_{\mathrm{Nd}} \sim-14\right)$ [Goldstein et al., 1997], relative to Amazon River sediments $\left(\varepsilon_{\mathrm{Nd}} \sim-9.2\right)$ [Goldstein et al., $1984]$, which presumably would have made the $\varepsilon_{\mathrm{Nd}}$ values during MIS 4 less radiogenic than those recorded in this study.

[27] The lower silicic acid content at the MD99-2198 core site during MIS 5a is consistent with the greater influence of northern waters inferred from the $\mathrm{Nd}$ isotope data. The apparent increase in silicic acid concentration observed during MIS 4 leads us to question whether the inferred changes in silicic acid concentration are due to an increase in the volumetric contribution of AAIW to the Tobago Basin, to an increase in its preformed silicic acid concentration, or both. Records of the $\delta^{30} \mathrm{Si}$ of diatoms from the Atlantic sector of the SO show more depleted $\delta^{30} \mathrm{Si}$ values during MIS 4, which has been interpreted as an indication of lower silicic acid utilization by diatoms in the Atlantic SO, and an increase in the silicic acid content of SO surface waters by corollary [Brzezinski et al., 2002]. This lends support to the argument for an increased silicic acid content of AAIW during MIS 4. Furthermore, the apparent decoupling between our records of $\varepsilon_{\mathrm{Nd}}$ and $\delta^{30} \mathrm{Si}$ during early MIS 4 suggests that the increase in AAIW influence at the site of MD99-2198 did not itself drive the inferred change in silicic acid concentration.

[28] A study of $\delta^{13} \mathrm{C}$ in benthic foraminifera from the southeast Pacific (east of New Zealand) suggested lower glacial formation rates of AAIW for the past three G-IG cycles [Pahnke and Zahn, 2005; Crosta et al., 2007]. However, Pahnke and Zahn [2005] also acknowledge that similar glacial excursions in benthic $\delta^{13} \mathrm{C}$ could have been produced by upward displacement of the boundary between AAIW and Upper Circumpolar Deep Water (UCDW), which exhibits more depleted glacial $\delta^{13} \mathrm{C}$ values [Hodell et al., 2003]. Spatial displacement of the AAIW-UCDW boundary is consistent with the inferred movement of westerly wind belts equatorward during glacial periods [Toggweiler et al., 2006]. Additionally, positive $\delta^{13} \mathrm{C}$ excursions interpreted by Pahnke and Zahn as periods of enhanced AAIW formation are correlated with periods of enhanced upwelling inferred from increased opal fluxes, recorded near the APF in the Atlantic sector of the SO [Anderson et al., 2009]. A more southerly position of the westerly wind belt increases upwelling while simultaneously displacing the AAIW-UCDW boundary southward and downward near the core site used in the Pahnke and Zahn study. Furthermore, a number of benthic $\delta^{13} \mathrm{C}$ records from various depths around New Zealand support the notion of displacement of the AAIW-UCDW boundary [Elmore et al., 2011]. While the debate surrounding AAIW formation rates remains unresolved, we argue that there is no inconsistency between our inference of increased AAIW expression in the middepth western tropical Atlantic during MIS 4 and the benthic $\delta^{13} \mathrm{C}$ record of Pahnke and Zahn [2005].

\section{Controls on Low-Latitude Diatom Productivity}

[29] Elevated silicic acid in AAIW influencing the middepth western tropical Atlantic during MIS 4 appears to have been unable to reach the euphotic zone there and was therefore prevented from promoting greater diatom export productivity in the Tobago Basin, based on the opal record from MD99-2198 (Figure 5, purple curve f). A lack of upwelling in this interval may have been related to the depth of the western Atlantic thermocline, which is thought to have deepened throughout MIS 4 [Rühlemann et al., 1996; Höll et al., 1999].

[30] Conversely, in the EEA, the thermocline appears to have been shallower than it was in the western Atlantic during MIS 4 [Abrantes, 2000; Flores et al., 2000], due to enhanced northeast trade wind strength [Flores et al., 2000; Abrantes, 2003] and greater rates of upwelling [Jansen et al., 1996; Abrantes, 2000]. This might explain why leaked silicic acid during MIS 4 may have been able to influence diatom export productivity in the EEA but not the western equatorial Atlantic (Figure 5). The maximum in opal flux observed in RC24-01 is aligned with maxima in F(TOC) and $\mathrm{U}_{\text {auth }}$, suggesting increased marine productivity during this interval (Figure 6), as well as opal maxima in other cores from across the EEA [Gardner and Burckle, 1975; Stabell, 1986; Abrantes, 2001]. In addition, a study of modern diatom productivity in the EEA found that the spatial pattern of opal burial reflects diatom productivity in the overlying waters despite only $0.05-3 \%$ of total opal being buried [Treppke et al., 1996]. This strongly implies that the increase in opal accumulation during MIS 4 was a result of enhanced diatom export productivity rather than enhanced opal preservation. Authigenic uranium $\left(\mathrm{U}_{\text {auth }}\right)$ has been used as a proxy for organic carbon flux [Kumar et al., 1995; Anderson et al., 1998; Chase et al., 2001] and provides support for the interpretation of an enhanced organic carbon flux during early MIS 4 from the F(TOC) record of RC24-01 (Figure 6, green curve c). Additionally, the interpretation of an overall enhancement in export productivity during MIS 4 is consistent with a paleoproductivity reconstruction using organic carbon and planktic foraminiferal transfer functions from a core taken from the EEA [Sarnthein et al., 1992].

[31] Despite the coincidence of the enrichment of the Atlantic thermocline with silicic acid and the enhancement of low-latitude opal export, the mechanism required to mix AAIW from depths of $800-1000 \mathrm{~m}$ into the euphotic zone $(<200 \mathrm{~m})$ is as yet unidentified. On the other hand, SAMW has also been invoked as a major conduit for preformed nutrients to the low latitudes [Sarmiento et al., 2004] and has the potential to alleviate low-latitude Si limitation of diatom productivity, presumably being more readily entrained into the euphotic zone. A recent ocean circulation experiment using the Hybrid isopycnic-Cartesian Coordinate Ocean general circulation Model (HYCOM) has demonstrated that SAMW-related tracer reemergence in the Atlantic at tropical 
latitudes may be strongly dependent on shear-induced turbulent mixing and furthermore that significant tracer reemergence occurs in the North Atlantic [Zuo et al., 2012].

[32] The record of sedimentary opal from ODP 1063 (Bermuda Rise) is in line with results from a number of cores from the EEA, in that it shows an increase during MIS 4. Following previous studies [Keigwin and Boyle, 2008; Gil et al., 2009; Lippold et al., 2009], we interpret the record of percent opal in ODP 1063 as reflecting increased diatom productivity at the Bermuda Rise. These findings imply that the northward penetration of AAIW may have been enhanced relative to its modern extent [Schlitzer, 2000] during northern cold intervals (D-O 19 and 20) and are also in agreement with the findings of Pahnke et al. [2008]. Today, the Bermuda Rise is a stratified, oligotrophic environment with low diatom productivity [Heath, 1974], but the site has witnessed significant increases in diatom productivity in the past [Keigwin and Boyle, 2008; Gil et al., 2009; Lippold et al., 2009]. Processes such as cold-core rings and mode water eddies may have enabled silicic acid within AAIW/SAMW to be brought into the euphotic zone and therefore to have enhanced diatom productivity [The Ring Group, 1981; Krause et al., 2009]. Melting icebergs are also thought to have had the potential to affect diatom export productivity in waters overlying the Bermuda Rise, possibly due to their amplification of cold-core rings [Gil et al., 2009]. Aeolian input of Fe can probably be ruled out as an influence on diatom productivity at the Bermuda Rise, as experiments have shown that Fe input at the Bermuda Atlantic Time-series Study site near Bermuda failed to stimulate diatom productivity [Nelson and Brzezinski, 1997]. Nonetheless, the coincidence of large increases in diatom productivity in oligotrophic areas of the ocean with our new evidence for silicic acid leakage from high southern latitudes is compelling and suggests that the processes are somehow related.

[33] More work is needed to constrain the amount of silicic acid leakage before accepting that a SALH scenario was responsible for the enhanced sedimentary opal observed in ODP 1063 during MIS 4. Additional comparisons of thorium-normalized opal flux rates with other proxies (for example, past eolian silicon input) are required in order to better understand the controls on diatom export productivity at the Bermuda Rise.

\section{Possible Influence of Silicic Acid Leakage on $\mathrm{pCO}_{2}$ During MIS 4}

[34] The most fundamental component of the SALH is its prediction of a decrease in the low-latitude export ratio of inorganic to organic carbon $\left(\mathrm{CaCO}_{3}: \mathrm{C}_{\text {org }}\right.$ rain ratio) [Matsumoto et al., 2002]. Hence, if the increase in diatom productivity observed here caused a change in the $\mathrm{CaCO}_{3}$ : $\mathrm{C}_{\text {org }}$ rain ratio, it should be manifest in the record of $p \mathrm{CO}_{2}$ [Archer et al., 2000; Sigman and Boyle, 2000]. A box modeling study of the SALH scenario suggested that the potential $p \mathrm{CO}_{2}$ drawdown associated with low-latitude changes in the carbonate pump and carbonate compensation feedbacks could cause a 35-45 ppmv reduction in $\mathrm{pCO}_{2}$ [Matsumoto et al., 2002]. This finding leaves open the possibility that the SALH may have had a significant impact on $p \mathrm{CO}_{2}$ drawdown during MIS 4. However, our records suggest that the $p \mathrm{CO}_{2}$ drawdown associated with the SALH probably occurred over longer timescales (throughout MIS 4 (Figure 5)), and thus, we suggest that the rapid $p \mathrm{CO}_{2}$ decrease seen at the start of MIS 4 is more likely to have been the result of some combination of physical oceanographic mechanisms, with further significant contributions from marine biota [Hain et al., 2010; Sigman et al., 2010; Thornalley et al., 2013].

[35] Finally, we note a recent study by Meckler et al. [2013] concluded that increased opal production in the tropical Atlantic during the last deglaciation corresponded to a decrease in the supply of AAIW to the Atlantic basin during Heinrich Stadial (HS) 1. While our study cannot be compared directly with that of Meckler et al. (ours is concerned with the transition into a glacial state as opposed to a deglacial transition: MIS 4 should not be viewed as analogous to an HS event), our findings do suggest that changes in the silicic acid concentration of AAIW are possible and highlight the value of reconstructing variations in the source and nutrient chemistry of potential source waters for low-latitude opal production.

\section{Conclusions}

[36] Our $\varepsilon_{\mathrm{Nd}}$ and $\delta^{30} \mathrm{Si}$ records from the Tobago Basin provide the first direct evidence of silicic acid leakage in glacial-aged AAIW. Patterns of opal production in the eastern equatorial Atlantic and sedimentary opal content in the northwest Atlantic during MIS 4 support the interpretation of silicic acid leakage to low latitudes and the subsequent enhancement of diatom primary productivity over carbonatebased primary productivity, consistent with the SALH. Based on our records, the SALH was probably not the primary driver of the 46 ppmv $p \mathrm{CO}_{2}$ decrease observed at the initiation of MIS 4 but could nonetheless have contributed to $p \mathrm{CO}_{2}$ drawdown later in MIS 4 with the development of full glacial conditions.

[37] Acknowledgments. We thank Dirk Nürnberg (MARUM Kiel) for the assistance with sampling MD99-2198, Rusty Lotti and George Lozefski (Lamont-Doherty Earth Observatory Deep-Sea Sample Repository) for the assistance with sampling RC24-01, and Rebecca Pyne for the initial sampling of ODP 1063. We thank Julia Becker for running stable isotope samples, Rainer Zahn for permitting us to plot unpublished benthic $\delta^{18} \mathrm{O}$ data from MD99-2198, David Verardo for supplying $\delta^{18} \mathrm{O}$ data from RC24-01, Marty Fleisher for the laboratory assistance and helpful discussion in obtaining protactinium and thorium data on RC24-01 at the LamontDoherty Earth Observatory, and Katharina Kreissig, Claire Huck, and Carys Cook (Imperial College London MAGIC Group) for the laboratory assistance and running extra neodymium samples. The work is part of a wider project on the MIS 5/4 transition, supervised by S. B. and supported by NERC (UK) grant NE/F002734/1. K.R.H. is funded by National Science Foundation grant MCG-1029986. Si isotope samples were analyzed at the WHOI ICP Facility. T.v.d.F. acknowledges funding from the European Commission (IRG 230828)

\section{References}

The Ring Group (1981), Gulf stream cold-core rings: Their physics, chemistry, and biology, Science, 212(4499), 1091-1100.

Abrantes, F. (2000), 200,000 yr diatom records from Atlantic upwelling sites reveal maximum productivity during LGM and a shift in phytoplankton community structure at 185,000 yr, Earth Planet. Sci. Lett., 176(1), 7-16.

Abrantes, F. (2001), Assessing the Ethmodiscus ooze problem: New perspective from a study of an eastern equatorial Atlantic core, Deep Sea Res., Part I, 48(1), 125-135.

Abrantes, F. (2003), A 340,000 year continental climate record from tropical Africa-News from opal phytoliths from the equatorial Atlantic, Earth Planet. Sci. Lett., 209(1-2), 165-179.

Ahn, J., and E. J. Brook (2008), Atmospheric $\mathrm{CO}_{2}$ and climate on millennial time scales during the last glacial period, Science, 322(5898), 83-85. 
Andersen, K. K., et al. (2007), Greenland Ice Core Chronology 2005 (GICC05) and 20 year means of oxygen isotope data from ice core NGRIP, in Pangaea, edited., doi:10.1594/PANGAEA.586838.

Anderson, R. F., and A. P. Fleer (1982), Determination of natural actinides and plutonium in marine particulate material, Anal. Chem., 54(7), $1142-1147$.

Anderson, R. F., N. Kumar, R. A. Mortlock, P. N. Froelich, P. Kubik, B. Dittrich-Hannen, and M. Suter (1998), Late-Quaternary changes in productivity of the Southern Ocean, J. Mar. Syst., 17(1-4), 497-514.

Anderson, R. F., S. Ali, L. I. Bradtmiller, S. H. H. Nielsen, M. Q. Fleisher, B. E. Anderson, and L. H. Burckle (2009), Wind-driven upwelling in the Southern Ocean and the deglacial rise in atmospheric $\mathrm{CO}_{2}$, Science, 323(5920), 1443-1448.

Archer, D., and E. Maier-Reimer (1994), Effect of deep-sea sedimentary calcite preservation on atmospheric $\mathrm{CO}_{2}$ concentration, Nature, 367(6460), $260-263$

Archer, D., A. Winguth, D. Lea, and N. Mahowald (2000), What caused the glacial/interglacial atmospheric $\mathrm{pCO}_{2}$ cycles?, Rev. Geophys., 38(2), 159-189, doi:10.1029/1999RG000066.

Barker, S., G. Knorr, R. L. Edwards, F. Parrenin, A. E. Putnam, L. C. Skinner, E Wolff, and M. Ziegler (2011), 800,000 years of abrupt climate variability, Science, 334(6054), 347-351.

Barnola, J. M., D. Raynaud, Y. S. Korotkevich, and C. Lorius (1987), Vostok ice core provides 160,000-year record of atmospheric $\mathrm{CO}_{2}$, Nature, 329(6138), 408-414.

Bayon, G., C. R. German, R. M. Boella, J. A. Milton, R. N. Taylor, and R. W. Nesbitt (2002), An improved method for extracting marine sediment fractions and its application to $\mathrm{Sr}$ and $\mathrm{Nd}$ isotopic analysis, Chem. Geol., 187(3-4), 179-199.

Berger, W. H. (1982), Increase of carbon dioxide in the atmosphere during deglaciation: The coral reef hypothesis, Naturwissenschaften, 69, 87-88.

Bertram, C. J., and H. Elderfield (1993), The geochemical balance of the rare earth elements and neodymium isotopes in the oceans, Geochim. Cosmochim. Acta, 57(9), 1957-1986.

Beucher, C. P., M. A. Brzezinski, and X. Crosta (2007), Silicic acid dynamics in the glacial sub-Antarctic: Implications for the silicic acid leakage hypothesis, Global Biogeochem. Cycles, 21, GB3015, doi:10.1029/ 2006GB002746.

Bourles, B., R. L. Molinari, E. Johns, W. D. Wilson, and K. D. Leaman (1999), Upper layer currents in the western tropical North Atlantic (1989-1991), J. Geophys. Res., 104(C1), 1361-1375, doi:10.1029/ $1998 \mathrm{jc} 900025$.

Bowles, F. A., and P. Fleischer (1985), Orinoco and Amazon River sediment input to the eastern Caribbean Basin, Mar. Geol., 68(1-4), 53-72.

Broecker, W. S. (1982), Glacial to interglacial changes in ocean chemistry, Prog. Oceanogr., 2, 151-197.

Brzezinski, M. A., D. M. Nelson, V. M. Franck, and D. E. Sigmon (2001), Silicon dynamics within an intense open-ocean diatom bloom in the Pacific sector of the Southern Ocean, Deep Sea Res., Part II, 48(19-20), 3997-4018.

Brzezinski, M. A., C. J. Pride, V. M. Franck, D. M. Sigman, J. L. Sarmiento, K. Matsumoto, N. Gruber, G. H. Rau, and K. H. Coale (2002), A switch from $\mathrm{Si}(\mathrm{OH})_{4}$ to $\mathrm{NO}_{3}^{-}$depletion in the glacial Southern Ocean, Geophys. Res. Lett., 29(12), 1564-1567, doi:10.1029/2001GL014349.

Cardinal, D., L. Y. Alleman, F. Dehairs, N. Savoye, T.W. Trull, and L. André (2005), Relevance of silicon isotopes to Si-nutrient utilization and Si-source assessment in Antarctic waters, Global Biogeochem. Cycles, 19, GB2007, doi:10.1029/2004GB002364.

Chase, Z., R. F. Anderson, and M. Q. Fleisher (2001), Evidence from authigenic uranium for increased productivity of the glacial subantarctic ocean, Paleoceanography, 16(5), 468-478, doi:10.1029/2000PA000542.

Chérubin, L. M., and P. L. Richardson (2007), Caribbean current variability and the influence of the Amazon and Orinoco freshwater plumes, Deep Sea Res., Part I, 54(9), 1451-1473.

Crosta, X., C. Beucher, K. Pahnke, and M. A. Brzezinski (2007), Silicic acid leakage from the Southern Ocean: Opposing effects of nutrient uptake and oceanic circulation, Geophys. Res. Lett., 34, L13601, doi:10.1029/ 2006GL029083.

Cruz, F. W., S. J. Burns, I. Karmann, W. D. Sharp, M. Vuille, A. O. Cardoso, J. A. Ferrari, P. L. Silva Dias, and O. Viana (2005), Insolation-driven changes in atmospheric circulation over the past 116,000 years in subtropical Brazil, Nature, 434(7029), 63-66.

Curry, W. B., and D. W. Oppo (2005), Glacial water mass geometry and the distribution of $\mathrm{d} 13 \mathrm{C}$ of $\mathrm{TCO}_{2}$ in the western Atlantic Ocean, Paleoceanography, 20, PA1017, doi:10.1029/2004PA001021.

de Souza, G. F., B. C. Reynolds, J. Rickli, M. Frank, M. A. Sato, L. J. A. Gerringa, and B. Bourdon (2012), Southern Ocean control of silicon stable isotope distribution in the deep Atlantic Ocean, Global Biogeochem. Cycles, 26, GB2035, doi:10.1029/2011GB004141.

Egge, J. K., and D. L. Aksnes (1992), Silicate as regulating nutrient in phytoplankton competition, Mar. Ecol. Prog. Ser., 83, 281-289.
Elmore, A. C., E. L. Sikes, M. S. Cook, B. Schiraldi, and T. Guilderson (2011), Enhanced Southern Ocean Ventilation Through the Last Deglaciation, paper presented at 2011 Fall Meeting, AGU, San Francisco, Calif.

Fleisher, M. Q., and R. F. Anderson (2003), Assessing the collection efficiency of Ross Sea sediment traps using ${ }^{230} \mathrm{Th}$ and ${ }^{231} \mathrm{~Pa}$, Deep Sea Res. Part II, 50(3-4), 693-712.

Flores, J. A., M. A. Bárcena, and F. J. Sierro (2000), Ocean-surface and wind dynamics in the Atlantic Ocean off Northwest Africa during the last 140,000 years, Palaeogeogr. Palaeoclimatol., Palaeoecol., 161(3-4), 459-478.

Foster, G. L., D. Vance, and J. Prytulak (2007), No change in the neodymium isotope composition of deep water exported from the North Atlantic on glacial-interglacial time scales, Geology, 35(1), 37-40.

Gardner, J. V., and L. H. Burckle (1975), Upper Pleistocene Ethmodiscus rex oozes from the eastern equatorial Atlantic, Micropaleontology, 21(2), 236-242.

Georg, R. B., A. J. West, A. R. Basu, and A. N. Halliday (2009), Silicon fluxes and isotope composition of direct groundwater discharge into the Bay of Bengal and the effect on the global ocean silicon isotope budget, Earth Planet. Sci. Lett., 283, 67-74.

Gil, I. M., L. D. Keigwin, and F. G. Abrantes (2009), Deglacial diatom productivity and surface ocean properties over the Bermuda Rise, northeast Sargasso Sea, Paleoceanography, 24, PA4101, doi:10.1029/2008PA001729.

Goldstein, S. L., R. K. O’Nions, and P. J. Hamilton (1984), A Sm-Nd isotopic study of atmospheric dusts and particulates from major river systems, Earth Planet. Sci. Lett., 70(2), 221-236.

Goldstein, S. L., N. T. Arndt, and R. F. Stallard (1997), The history of a continent from U-Pb ages of zircons from Orinoco River sand and Sm-Nd isotopes in Orinoco basin river sediments, Chem. Geol., 139(1-4), 271-286.

Grützner, J., et al. (2002), Astronomical age models for Pleistocene drift sediments from the western North Atlantic (ODP sites 1055-1063), Mar. Geol., 189(1-2), 5-23.

Guihou, A., S. Pichat, S. Nave, A. Govin, L. Labeyrie, E. Michel, and C. Waelbroeck (2010), Late slowdown of the Atlantic Meridional Overturning Circulation during the last glacial inception: New constraints from sedimentary $\left({ }^{231} \mathrm{~Pa} /{ }^{230} \mathrm{Th}\right)$, Earth Planet. Sci. Lett., 289(3-4), 520-529.

Gutjahr, M., M. Frank, C. H. Stirling, V. Klemm, T. van de Flierdt, and A. N. Halliday (2007), Reliable extraction of a deepwater trace metal isotope signal from $\mathrm{Fe}-\mathrm{Mn}$ oxyhydroxide coatings of marine sediments, Chem. Geol., 242(3-4), 351-370.

Gutjahr, M., M. Frank, C. H. Stirling, L. D. Keigwin, and A. N. Halliday (2008), Tracing the Nd isotope evolution of North Atlantic Deep and Intermediate Waters in the western North Atlantic since the Last Glacial Maximum from Blake Ridge sediments, Earth Planet. Sci. Lett., 266(1-2), 61-77.

Haddad, G. A., and A. W. Droxler (1996), Metastable $\mathrm{CaCO}_{3}$ dissolution at intermediate water depths of the Caribbean and western North Atlantic: Implications for intermediate water circulation during the past 200,000 years, Paleoceanography, 11(6), 701-716, doi:10.1029/96PA02406.

Hain, M. P., D. M. Sigman, and G. H. Haug (2010), Carbon dioxide effects of Antarctic stratification, North Atlantic Intermediate Water formation, and subantarctic nutrient drawdown during the last ice age: Diagnosis and synthesis in a geochemical box model, Global Biogeochem. Cycles, 24, GB4023, doi:10.1029/2010GB003790.

Haley, B. A., G. P. Klinkhammer, and J. McManus (2004), Rare earth elements in pore waters of marine sediments, Geochim. Cosmochim. Acta, 68(6), 1265-1279.

Hanawa, K., and L. D. Talley (2001), Mode waters, in Ocean Circulation and Climate, edited by G. Siedler, and J. Church, pp. 373-386, Academic, San Diego, Calif

Heath, G. R. (1974), Dissolved silica and deep-sea sediments, in Society of Economic Paleontologists and Mineralogists Special Publication, edited by W. W. Hay, pp. 77-93.

Hendry, K. R., and L. F. Robinson (2012), The relationship between silicon isotope fractionation in sponges and silicic acid concentration: Modern and core-top studies of biogenic opal, Geochim. Cosmochim. Acta, 81 $1-12$.

Hendry, K. R., R. B. Georg, R. E. M. Rickaby, L. F. Robinson, and A. N. Halliday (2010), Deep ocean nutrients during the Last Glacial Maximum deduced from sponge silicon isotopic compositions, Earth Planet. Sci. Lett., 292, 290-300.

Hodell, D. A., K. A. Venz, C. D. Charles, and U. S. Ninnemann (2003), Pleistocene vertical carbon isotope and carbonate gradients in the South Atlantic sector of the Southern Ocean, Geochem. Geophys. Geosyst., 4(1), 1004, doi:10.1029/2002GC000367.

Höll, C., B. Karwath, C. Rühlemann, K. A. F. Zonneveld, and H. Willems (1999), Palaeoenvironmental information gained from calcareous dinoflagellates: The late Quaternary eastern and western tropical Atlantic Ocean in comparison, Palaeogeogr. Palaeoclimatol. Palaeoecol., 146(1-4), $147-164$ 
Hüls, M., and R. Zahn (2000), Millennial-scale sea surface temperature variability in the western tropical North Atlantic from planktonic foraminiferal census counts, Paleoceanography, 15(6), 659-678, doi:10.1029/ 1999PA000462.

Jacobsen, S. B., and G. J. Wasserburg (1980), Sm-Nd isotopic evolution of chondrites, Earth Planet. Sci. Lett., 50(1), 139-155.

Jansen, J. H. F., E. Ufkes, and R. R. Schneider (1996), Late Quaternary movements of the Angola-Benguela Front SE Atlantic and implications for advection in the equatorial ocean, in The South Atlantic: Past and Present Circulation, edited by G. Wefer, et al., pp. 553-575, Springer, Berlin.

Jeandel, C. (1993), Concentration and isotopic composition of $\mathrm{Nd}$ in the South Atlantic Ocean, Earth Planet. Sci. Lett., 117(3-4), 581-591.

Jeandel, C., D. Thouron, and M. Fieux (1998), Concentrations and isotopic compositions of neodymium in the eastern Indian Ocean and Indonesian straits, Geochim. Cosmochim. Acta, 62(15), 2597-2607.

Keigwin, L. D., and E. A. Boyle (2008), Did North Atlantic overturning halt 17,000 years ago?, Paleoceanography, 23, PA1101, doi:10.1029/ 2007PA001500.

Keigwin, L. D., W. B. Curry, S. J. Lehman and S. Johnsen (1994), The role of the deep ocean in North Atlantic climate change between 70 and 130 kyr ago, Nature, 371(6495), 323-326.

Krause, J. W., M. W. Lomas, and D. M. Nelson (2009), Biogenic silica at the Bermuda Atlantic Time-series Study site in the Sargasso Sea: Temporal changes and their inferred controls based on a 15-year record, Global Biogeochem. Cycles, 23, GB3004, doi:10.1029/2008GB003236.

Kumar, N., R. F. Anderson, R. A. Mortlock, P. N. Froelich, P. Kubik, B. Dittrich-Hannen, and M. Suter (1995), Increased biological productivity and export production in the glacial Southern Ocean, Nature, 378(6558), 675-680.

Lacan, F., and C. Jeandel (2005), Acquisition of the neodymium isotopic composition of the North Atlantic Deep Water, Geochem. Geophys. Geosyst., 6, Q12008, doi:10.1029/2005GC000956.

Lea, D. W., D. K. Pak, L. C. Peterson, and K. A. Hughen (2003), Synchroneity of tropical and high-latitude Atlantic temperatures over the last glacial termination, Science, 301(5638), 1361-1364.

Leblanc, K., et al. (2009), Distribution of calcifying and silicifying phytoplankton in relation to environmental and biogeochemical parameters during the late stages of the 2005 North East Atlantic Spring Bloom, Biogeosciences, 6, 2155-2179.

Levitus, S., M. E. Conkright, J. L. Reid, R. G. Najjar, and A. Mantyla (1993), Distribution of nitrate, phosphate and silicate in the world oceans, Prog. Oceanogr., 31(3), 245-273.

Lewis, W., and J. Saunders (1989), Concentration and transport of dissolved and suspended substances in the Orinoco River, Biogeochemistry, 7(3), 203-240.

Lippold, J., J. Grützner, D. Winter, Y. Lahaye, A. Mangini, and M. Christ (2009), Does sedimentary ${ }^{231} \mathrm{~Pa} /{ }^{230} \mathrm{Th}$ from the Bermuda Rise monitor past Atlantic Meridional Overturning Circulation?, Geophys. Res. Lett. 36, L12601, 10.1029/2009GL038068.

Marañón, E., E. Fernández, R. P. Harris, and D. S. Harbour (1996), Effects of the diatom-Emiliania huxleyi succession on photosynthesis, calcification and carbon metabolism by size-fractionated phytoplankton, Hydrobiologia, 317 189-199.

Marchitto, T. M., and W. S. Broecker (2006), Deep water mass geometry in the glacial Atlantic Ocean: A review of constraints from the paleonutrient proxy $\mathrm{Cd} / \mathrm{Ca}$, Geochem. Geophys. Geosyst., 7, Q12003, doi:10.1029/ 2006GC001323.

Martin, J. H. (1990), Glacial-interglacial CO2 change: The iron hypothesis, Paleoceanography, 5(1), 1-13, doi:10.1029/PA005i001p00001.

Martinson, D. G., N. G. Pisias, J. D. Hays, J. Imbrie, T. C. Moore Jr., and N. J. Shackleton (1987), Age dating and the orbital theory of the ice ages: Development of a high-resolution 0 to 300,000-year chronostratigraphy, Quat. Res., 27(1), 1-29

Matsumoto, K., and J. L. Sarmiento (2008), A corollary to the silicic acid leakage hypothesis, Paleoceanography, 23, PA2203, doi:10.1029/2007PA001515.

Matsumoto, K., J. L. Sarmiento, and M. A. Brzezinski (2002), Silicic acid leakage from the Southern Ocean: A possible explanation for glacial atmospheric $\mathrm{pCO}_{2}$, Global Biogeochem. Cycles, 16(3), 1031, doi:10.1029/ 2001GB001442.

McCartney, M. S. (1977), Subantarctic Mode Water, in A Voyage of Discovery, edited by M. Angel, pp. 103-119, Pergamon.

McManus, J. F., R. Francois, J. M. Gherardi, L. D. Keigwin, and S. Brown-Leger (2004), Collapse and rapid resumption of Atlantic meridional circulation linked to deglacial climate changes, Nature, 428(6985), 834-837.

Meckler, A. N., D. M. Sigman, K. A. Gibson, R. François, A. Martínez-García, S. L. Jaccard, U. Röhl, L. C. Peterson, R. Tiedemann and G. H. Haug (2013), Deglacial pulses of deep-ocean silicate into the subtropical North Atlantic Ocean, Nature, 495(7442), 495-498.
Meredith, M. P., K. E. Grose, E. L. McDonagh, K. J. Heywood, R. D. Frew, and P. F. Dennis (1999), Distribution of oxygen isotopes in the water masses of Drake Passage and the South Atlantic, J. Geophys. Res., 104(C9), 20,949-20,962, doi:10.1029/98jc02544.

Molleri, G. S. F., E. M. L. d. M. Novo, and M. Kampel (2010), Space-time variability of the Amazon River plume based on satellite ocean color, Cont. Shelf Res., 30(3-4), 342-352.

Mortlock, R. A., and P. N. Froelich (1989), A simple method for the rapid determination of biogenic opal in pelagic marine sediments, Deep Sea Res., Part A, 36(9), 1415-1426.

Nelson, D. M., and M. A. Brzezinski (1997), Diatom growth and productivity in an oligotrophic midocean gyre: A 3-yr record from the Sargasso Sea near Bermuda, Limnol. Oceanogr., 43, 473-486.

Nelson, D. M., P. Tréguer, M. A. Brzezinski, A. Leynaert, and B. Quéguiner (1995), Production and dissolution of biogenic silica in the ocean: Revised global estimates, comparison with regional data and relationship to biogenic sedimentation, Global Biogeochem. Cycles, 9(3), 359-372, doi:10.1029/95gb01070.

Oppo, D. W., and S. J. Lehman (1993), Mid-depth circulation of the subpolar North Atlantic during the last glacial maximum, Science, 259(5098), $1148-1152$.

Pahnke, K., and R. Zahn (2005), Southern Hemisphere water mass conversion linked with North Atlantic climate variability, Science, 307(5716), 1741-1746.

Pahnke, K., S. L. Goldstein, and S. R. Hemming (2008), Abrupt changes in Antarctic Intermediate Water circulation over the past 25,000 years, Nat. Geosci., 1, 870-874.

Peeters, F. J. C., R. Acheson, G.-J. A. Brummer, W. P. M. de Ruijter, R. R. Schneider, G. M. Ganssen, E. Ufkes, and D. Kroon (2004) Vigorous exchange between the Indian and Atlantic Oceans at the end of the past five glacial periods, Nature, 430(7000), 661-665.

Peterson, L. C., and G. H. Haug (2006), Variability in the mean latitude of the Atlantic Intertropical Convergence Zone as recorded by riverine input of sediments to the Cariaco Basin (Venezuela), Palaeogeogr. Palaeoclimatol. Palaeoecol., 234(1), 97-113.

Peterson, L. C., G. H. Haug, K. A. Hughen, and U. Röhl (2000), Rapid changes in the hydrologic cycle of the tropical Atlantic during the last glacial, Science, 290(5498), 1947-1951.

Petit, J. R., et al. (1999), Climate and atmospheric history of the past 420,000 years from the Vostok ice core, Antarctica, Nature, 399(6735), $429-436$.

Piepgras, D. J., and G. J. Wasserburg (1982), Isotopic composition of neodymium in waters from the Drake Passage, Science, 217(4556), 207-214.

Piepgras, D. J., and G. J. Wasserburg (1987), Rare earth element transport in the western North Atlantic inferred from $\mathrm{Nd}$ isotopic observations, Geochim. Cosmochim. Acta, 51(5), 1257-1271.

Piotrowski, A. M., S. L. Goldstein, S. R. Hemming, and R. G. Fairbanks (2005), Temporal relationships of carbon cycling and ocean circulation at glacial boundaries, Science, 307(5717), 1933-1938.

Pondaven, P., O. Ragueneau, P. Treguer, A. Hauvespre, L. Dezileau, and J. L. Reyss (2000), Resolving the "opal paradox" in the Southern Ocean, Nature, 405(6783), 168-172

Ragueneau, O., et al. (2000), A review of the Si cycle in the modern ocean: Recent progress and missing gaps in the application of biogenic opal as a paleoproductivity proxy, Global Planet. Change, 26(4), 317-365.

Robinson, L. F., and T. van de Flierdt (2009), Southern Ocean evidence for reduced export of North Atlantic Deep Water during Heinrich event 1 , Geology, 37(3), 195-198.

de la Rocha, C., M. A. Brzezinski, and M. J. DeNiro (1997), Fractionation of silicon isotopes by marine diatoms during biogenic silica formation, Geochim. Cosmochim. Acta, 61, 5051-6.

Rogerson, M., P. P. E. Weaver, E. J. Rohling, L. J. Lourens, J. W. Murray, and A. Hayes (2006), Colour logging as a tool in high-resolution palaeoceanography, in New Techniques in Sediment Core Analysis, edited by R. G. Rothwell, Geol. Soc. Spec. Publ., 267, pp. 99-112.

Rühlemann, C., M. Frank, W. Hale, A. Mangini, S. Mulitza, P. J. Müller, and G. Wefer (1996), Late Quaternary productivity changes in the western equatorial Atlantic: Evidence from ${ }^{230}$ Th-normalized carbonate and organic carbon accumulation rates, Mar. Geol., 135(1-4), 127-152.

de Ruijter, W. P. M., A. Biastoch, S. S. Drijfhout, J. R. E. Lutjeharms, R. P. Matano, T. Pichevin, P. J. van Leeuwen, and W. Weijer (1999), Indian-Atlantic interocean exchange: Dynamics, estimation and impact, J. Geophys. Res., 104(C9), 20,885-20,910 doi:10.1029/1998JC900099.

Rutberg, R. L., S. R. Hemming, and S. L. Goldstein (2000), Reduced North Atlantic Deep Water flux to the glacial Southern Ocean inferred from neodymium isotope ratios, Nature, 405(6789), 935-938.

Sarmiento, J. L., and J. R. Toggweiler (1984), A new model for the role of the oceans in determining atmospheric $p \mathrm{CO}_{2}$, Nature, 308(5960), 621-624. 
Sarmiento, J. L., N. Gruber, M. A. Brzezinski, and J. P. Dunne (2004), Highlatitude controls of thermocline nutrients and low latitude biological productivity, Nature, 427(6969), 56-60.

Sarnthein, M., U. Pflaumann, R. Ross, R. Tiedemann, and K. Winn (1992), Transfer functions to reconstruct ocean palaeoproductivity: A comparison, in Upwelling Systems: Evolution Since the Early Miocene, edited by C. P. Summerhayes, W. L. Prell, and K. C. Emeis, Geol. Soc. Spec. Publ, 64, pp. 411-427.

Schlitzer, R. (2000), Electronic atlas of WOCE hydrographic and tracer data now available, Eos. Trans. $A G U, 81,45$.

Sievers, H. A., and W. D. Nowlin Jr. (1984), The stratification and water masses at Drake Passage, J. Geophys. Res., 89(C6), 10,489-10,514, doi:10.1029/JC089iC06p10489.

Sigman, D. M., and E. A. Boyle (2000), Glacial/interglacial variations in atmospheric carbon dioxide, Nature, 407(6806), 859-869.

Sigman, D. M., M. P. Hain, and G. H. Haug (2010), The polar ocean and glacial cycles in atmospheric $\mathrm{CO}_{2}$ concentration, Nature, 466(7302), 47-55.

Stabell, B. (1986), Variations of diatom flux in the eastern equatorial Atlantic during the last 400,000 years (METEOR cores 13519 and 13521), Mar. Geol., 72(3-4), 305-323.

Stichel, T., M. Frank, J. Rickli, and B. A. Haley (2012), The hafnium and neodymium isotope composition of seawater in the Atlantic sector of the Southern Ocean, Earth Planet. Sci. Lett., 317-318(1), 282-294.

Stramma, L., and F. Schott (1999), The mean flow field of the tropical Atlantic Ocean, Deep Sea Res., Part II, 46(1-2), 279-303.

Tachikawa, K., M. Roy-Barman, A. Michard, D. Thouron, D. Yeghicheyan, and C. Jeandel (2004), Neodymium isotopes in the Mediterranean Sea: Comparison between seawater and sediment signals, Geochim. Cosmochim. Acta, 68(14), 3095-3106.

Takeda, S. (1998), Influence of iron availability on nutrient consumption ratio of diatoms in oceanic waters, Nature, 393(6687), 774-777.

Thornalley, D. J. R., S. Barker, T. van de Flierdt, J. Becker, I. R. Hall, and G. Knorr (2013), Abrupt changes in deep Atlantic circulation during the transition to full glacial conditions, Paleoceanography, doi:10.1002/ palo.20025, in press.

Toggweiler, J. R., J. L. Russell, and S. R. Carson (2006), Midlatitude westerlies, atmospheric $\mathrm{CO}_{2}$, and climate change during the ice ages, Paleoceanography, 21, PA2005, 10.1029/2005PA001154.

Tréguer, P., D. M. Nelson, A. J. Van Bennekom, D. J. DeMaster, A. Leynaert, and B. Quéguiner (1995), The silica balance in the world ocean: A reestimate, Science, 268(5209), 375-379.
Treppke, U. F., C. B. Lange and G. Wefer (1996), Vertical fluxes of diatoms and silicoflagellates in the eastern equatorial Atlantic, and their contribution to the sedimentary record, Mar. Micropaleontol., 28, 73-96.

Tsuchiya, M. (1989), Circulation of the Antarctic Intermediate Water in the North Atlantic Ocean, J. Mar. Res., 47(4), 747-755.

van de Flierdt, T., L. F. Robinson, J. F. Adkins, S. R. Hemming, and S. L. Goldstein (2006), Temporal stability of the neodymium isotope signature of the Holocene to glacial North Atlantic, Paleoceanography, 21, PA4102, doi:10.1029/2006PA001294.

Verardo, D. J., and A. McIntyre (1994), Production and destruction: Control of biogenous in the tropical Atlantic 0-300,000 years B. P., Paleoceanography, 9(1), 63-86.

Voelker, A. H. L., S. M. Lebreiro, J. Schönfeld, I. Cacho, H. Erlenkeuser, and F. Abrantes (2006), Mediterranean outflow strengthening during Northern Hemisphere coolings: A salt source for the glacial Atlantic?, Earth Planet. Sci. Lett., 245(1-2), 39-55.

Vuille, M., R. S. Bradley, M. Werner, R. Healy, and F. Keimig (2003), Modeling $\mathrm{d}^{18} \mathrm{O}$ in precipitation over the tropical Americas: 1 Interannual variability and climatic controls, J. Geophys. Res., 108(D6), 4174, doi:10.1029/2001JD002038.

Wang, Y. J., H. Cheng, R. L. Edwards, Z. S. An, J. Y. Wu, C.-C. Shen, and J. A. Dorale (2001), A high-resolution absolute-dated late Pleistocene monsoon record from Hulu Cave, China, Science, 294(5550), 2345-2348.

Wang, Y., H. Cheng, R. L. Edwards, X. Kong, X. Shao, S. Chen, J. Wu, X. Jiang, X. Wang, and Z. An (2008), Millennial- and orbital-scale changes in the East Asian monsoon over the past 224,000 years, Nature 451(7182), 1090-1093.

Wille, M., J. Sutton, M. J. Ellwood, M. Sambridge, W. Maher, S. Eggins, and M. Kelly (2010), Silicon isotopic fractionation in marine sponges: A new model for understanding silicon isotopic fractionation in sponges, Earth Planet. Sci. Lett., 292(3-4), 281-289, doi:10.1016/j.eps1.2010.01.036.

Wüst, G. (1964), Stratification and Circulation of the Antillean-Caribbean Basins: Part 1. Spreading and Mixing of the Water Types With an Oceanographic Atlas. Columbia Univ. Press, New York.

Xie, R. C., F. Marcantonio, and M. W. Schmidt (2012), Deglacial variability of Antarctic Intermediate Water penetration into the North Atlantic from authigenic neodymium isotope ratios, Paleoceanography, 27, PA3221, doi:10.1029/2012PA002337.

Zuo, H., A. C. Naveira Garabato, A. L. New, and A. Oschlies (2012), Mechanisms of Subantarctic Mode Water upwelling in a hybridcoordinate global GCM, Ocean Modell., 45-46(0), 59-80. 